\title{
Accounting
}

\section{Political ties and performance of multinational corporations in Vietnamese emerging market}

\author{
An Thi Hong Nguyen ${ }^{a^{*}}$, Phuong V. Nguyen ${ }^{b}$ and Minh Ngoc Tuong Lya
}

${ }^{a}$ The School of Business, International University, Vietnam National University-Ho Chi Minh City, Vietnam ${ }^{b}$ Center for Public Administration, International University, Vietnam National University-Ho Chi Minh City, Vietnam

\begin{tabular}{l}
\hline C H R O N I C L E \\
\hline Article history: \\
Received February 22019 \\
Received in revised format \\
February 272020 \\
Accepted March 12020 \\
Available online \\
March 1 2020 \\
\hline Keywords: \\
MNCs \\
Political ties \\
Firm performance \\
Emerging market \\
Integrative approach
\end{tabular}

\section{A B S T R A C T}

Local governments play a key role in attracting foreign investment and the operations of multinational corporations (MNCs) in Vietnam, yet limited research has focused on the emerging issues in this context. This study adopted a mixed-methods approach. Representatives of MNCs in Ho Chi Minh City and four provinces participated in this research. Partial least squares structural equation modelling was used to analyze the data and test the model. The results reveal both direct and indirect relationships between political ties, institutional support, opportunity recognition and firm performance. Recommendations for the local governments are discussed in detail.

\section{Introduction}

Although still in a transitional stage, Vietnam has made much incredible economic and social advancement owing to the crucial contribution of foreign direct investment (FDI). In other words, FDI has become a significant contributor to Vietnam's economy. The annual average gross domestic product (GDP) growth rate is $8.2 \%$, which has created a foundation for socioeconomic development and improvement for the country's next stage of development (Ministry of Planning and Investment, 2018). FDI has also directly assisted in and promoted the creation of several industrial sectors with a high demand for technology and valueadded products, such as machinery manufacturing, energy, computers and telecommunications. Besides, Vietnam has proven to be a highly attractive market for both foreign and local companies wishing to establish themselves and develop. Several studies have indicated the benefits of international corporations operating in Vietnam such as the significant effect of productivity spill-over (Huynh, Nguyen, Trieu, \& Tran, 2019; Newman, Rand, Talbot, \& Tarp, 2015); the positive impact of externalities to domestic firms (Huynh, Tran, Nguyen, Le, \& Trieu, 2019). It is worth noting that FDI plays an essential role in the development of locations in many aspects, such as socioeconomics, science and information technology. However, to maintain and enhance the ability to attract FDI, governmental management and policy management play crucial roles as well. Highly efficient government management can improve the competitive advantage and attract foreign capital inflows, facilitate the effective management of registered projects, contribute positively to firm performance and minimize the risks related to less

* Corresponding author.

E-mail address: nthan@hemiu.edu.vn (A. T. H. Nguyen) 
efficient projects that do serious harm to the natural environment and society. From this perspective, it is important to open up the discussion of how foreign companies perceive governmental support aimed at enhancing their performance. This can not only help the firms understand how to use these political ties and governmental support but can also help the provincial governments understand the managers' needs.

Government connections are said to offer firms valuable resources, various institutional supports (Wang \& Lestari, 2013) and new sources of information and knowledge, which are not easily accessible, to gain a competitive advantage and consequently enhance their performance (Guo, Xu, \& Jacobs, 2014; Li \& Zhou, 2010; Tihanyi et al., 2019). Moreover, managers often leverage their network relationships to help their firm recognize more business opportunities in the industry (Kotabe, Jiang, \& Murray, 2011). Prior studies demonstrated a positive linkage between managerial political ties and firm performance (e.g. Guo et al., 2014; Li and Zhou, 2010; Peng and Luo, 2000). The main controversy in related studies is that managerial political ties assist firms in recognizing more business opportunities and provide the firms with various types of institutional support, such as valuable resources and information, to enhance their performance (Guo et al., 2014). However, the benefits that political ties offer to MNCs are difficult to evaluate. Specifically, Guo et al. (2014) mentioned that the fundamental underlying mechanisms that assist MNCs in turning managerial political ties into firm performance have not yet been examined thoroughly. Although numerous studies have tested the influence of this connection, understanding it thoroughly is essential for both foreign firms and local governments because each party can have a different perspective on how to utilize it.

Most studies on managerial political ties have focused on China, while the Vietnamese context has been underexplored. Recent empirical studies in Vietnam have mainly focused on the relationship between FDI and economic development (Nguyen, 2017), and spillover effects (Anwar \& Nguyen, 2014; Anwar \& Sun, 2014; Huynh et al., 2019; Le \& Pomfret, 2011; Thang, Pham, \& Barnes, 2016) (Huynh et al., 2019). A little study has examined the managerial political ties and supporting programmes of provincial governments in Vietnam from the perspective of MNCs. Thus, to address the limitations of previous research, this study was aimed at diving deeper into the relationship between political ties and MNC performance by investigating the role of mediators. Further, government support programmes for training activities in MNCs were examined. On the basis of our findings, we propose possible solutions for current and future firms to use political connections to boost firm performance through a particular mechanism. Moreover, we discuss the implications of our findings in terms of improving management's role in the provinces.

\section{Literature review}

\subsection{Managerial political ties}

Vietnam's economy is in a "late transition" stage, where institutional factors and market mechanisms are still developing and do not yet operate effectively. Yet, as Manolova et al. (2014) pointed out, stable network ties can support organizations by reducing obstacles and facilitating opportunities to enter the international market. In fact, several studies have shown that networks have a critical impact on organizations. For example, managerial ties can provide firms with scarce external resources and information (Kotabe et al., 2011; Podolny \& Page, 1998; Wang et al., 2013), offer a competitive advantage, open doors to business opportunities in the industry (Guo et al., 2014; Li and Zhou, 2010), and enable firms to enhance their legitimacy in a foreign market (Suchman, 1995). Consequently, firms tend to rely mostly on their network relationships as a substitution for different market mechanisms (McMillan \& Woodruff, 1999; Nguyen, 2005). However, for a venture in a transitional economy, a firm should invest significant effort in maintaining its networks to make the best use of resources and compensate for limitations in institutional factors (Manolova et al., 2014). The theoretical and empirical streams of the entrepreneurship literature have advocated the notion that networking has a positive relationship with desirable firm outcomes - namely, legitimacy, information exchange, coordination and business performance (Johannisson \& Monsted, 1998; Larson, 1991; Pollack et al., 2015; Tornikoski \& Newbert, 2007; Vissa \&Chacar, 2009). Managerial ties are defined as "boundary-spanning activities and personal relations" with the environment (Geletkanycz \& Hambrick, 1997). Although Peng and Luo (2000) divided managerial ties into political ties and business ties, the present study concentrated on the role of governmental management, but with a strong focus on political ties. Generally, this construct is described as the personal association of firm managers with government authorities at various levels as well as officials in industrial agencies and administrative centres (Peng and Luo, 2000). Ties play distinctive roles in the different environments in which a firm operates. At first sight, strong relations with the government assist an international firm in overcoming the so-called liability of foreignness (LOF) or the barriers that hinder performance in a new market (Chen et al., 2016; Choi \& Johanson, 2012).

Political ties are particularly valuable in a transition economy (Haiyang Li \& Zhang, 2007; Yu et al., 2014). In their study, Xin and Pearce (1996) found that in a developing context, the institution and regulation remained moderately weak. Chen et al. (2016) note that the rules in these countries are constantly changing and unpredictable. Vietnam is indeed in such a situation. Thus, the need to use political ties to survive and operate in this emerging market has become pressing. Managers rely on 
personal connections, especially with authoritative governmental officials and agencies, to facilitate business processes (Kotabe et al., 2011), supplement a fragmented institution, gain access to rare resources and valuable information, adapt to changes in regulations and break through complex administrative barriers (Faccio, 2010; Luo, 2003; Park and Luo, 2001; Xin and Pearce, 1996). More importantly, the government of an emerging country exercises control over businesses (Chen et al., 2016). Meanwhile, managerial ties are considered as a key factor that drives a firm success (Zhu, 2020). Consequently, maintaining a close relationship with the government provides a firm with bargaining power, which can offer a substantial competitive advantage in addition to the above-mentioned benefits. Last but not least, firms with a wide range of political ties are said to receive more benefits from promoting an ambidextrous concentration on both exploratory and exploitative innovation strategies (Yu et al., 2014). Thus, political ties can assist firms in various ways. First, securing institutional support is advantageous, and it can come in numerous variations (Guo et al., 2014; Li and Zhou, 2010). For instance, firms with close connections to highlevel political officials perform smoothly in all business activities, as managers can utilize these connections to effectively allocate resources and take other actions (Batjargal, 2003; Granovetter, 1985). Negotiation power over important resources, such as location and purchasing prices, is another example (Chen et al., 2016). The above advantages illustrate why foreign firms with political relationships are more successful in an emerging country like China (Tsang, 1998). Vietnam is no different. Like China, it has a history of economic instability including turbulence and various institutional changes. Institutional supports make governmental agencies more willing to help and less willing to restrict foreign firms, thereby facilitating business activities.

The second benefit is organizational legitimacy, which is even more vital in a relatively weak institutional and regulatory system (Xin and Pearce, 1996). Regulatory legitimacy refers to consistency between firm activities and the imperatives of the governing framework, and it is known to aid foreign firms in a new environment (Baum and Oliver, 1991). Although the law and regulations in Vietnam are becoming increasingly transparent, knowing the right person is crucial for maintaining legitimacy (Zhang and Li, 2008). Finally, a firm can utilize these important relations to gain market information for long-term planning and recognition of valuable opportunities (Bruton et al., 2010; Rao et al., 2000), which, in turn, can place the firm in a proactive role and increase its prosperity in the foreign market. Previous studies investigated the positive influence of political connections on firm performance. For example, Peng and Luo (2000) and Zhou et al. (2014) showed an improvement in firms' financial performance, such as return on asset (ROA), while Park and Luo (2001) observed an increase in sales growth. Guo et al. (2014) even illustrated the mediating role of institutional support and opportunity recognition between managerial ties and firm productivity in China. However, the above studies showed the same decline in the pattern of political ties over time. In other words, political ties can have a U-shape effect on firm performance. Jiang et al. (2018) show that as much as firms can benefit from political ties, relying too much on them might cause overembeddedness. We are aware of the well-noted reverse effect, also called the dark side of a political relationship, which can be partly explained by the fact that these connections often involve bribery (Warren et al., 2004). This action results in a huge financial cost to the firm and evinces low ethical standards, thus reducing its long-term reputation and sales. However, we argue that political ties, if used properly, are significant in an ambiguous context by providing more support, access to valuable information and resources as well as upholding legitimacy and market image.

\subsection{Firm performance}

To measure firm performance in the context of FDI, the present study relied on the two most prevalent approaches in previous studies. The first approach is the use of financial indicators, such as ROA, return on equity (ROE), return on sales (ROS) or net profit, debt, liquidity ratio collected from firms' financial reports. The second approach is a questionnaire for managers including both financial and non-financial indicators of firm performance, such as market share, competitiveness and corporate reputation in comparison with the main competitors. This second method is often used when several financial indicators are not published due to reasons of confidentiality. Another reason supporting the use of primary data relates to information transparency in the country where the research is conducted. In a context where transparency is low, the data may not reflect the nature of the "business performance" variable. Due to the difficulties that exist in collecting data and the transparency issues in financial reports in Vietnam, this study employed the latter approach to measure firm performance. The questionnaire was based on previous literature using the same techniques, including the three dimensions of market growth, financial performance and reputation (Guo et al., 2014; Jayaram \& Tan, 2010).

\subsection{Managerial political ties and their facilitators}

In emerging markets, governments build an industrial development plan and establish specific provisions to manage and guide economic activities (Guo et al., 2014). The practical studies of Li (2005) and Peng and Luo (2000) reveal that establishing connections with external bodies, such as political bodies, is a vital driver of superior firm performance. Therefore, creating connections with government officials and agencies can make industry policies and information more transparent to businesses (Hillman et al., 1999). Furthermore, the government plays an important role in improving the organizational legitimacy of a business or in refining the extent to which officials perceive that the operation of a business is consistent with the regulatory 
framework (Suchman, 1995). Besides, companies with strong political relationships can have better access to government support (Sheng et al., 2011) or the allocation of vital government resources, such as land and financial loans (Faccio, 2006; Khwaja and Mian, 2005; Xin and Pearce, 1996). These resources are key to firms' strengthening of their manufacturing process and competitive advantage. Overall, empirical studies conducted in China have provided evidence of the positive influence of political ties on firm performance (e.g. Chen et al., 2016; Guo et al., 2014; Li and Zhou, 2010; Peng \& Luo, 2000; Sheng et al., 2011). However, in a recent study on Iran Manufacturers, Sami, Rahnavard, \& Alavi Tabar (2019) find that business ties have a significant impact on firm performance, meanwhile political ties have no such impact. Therefore, we propose our first hypothesis:

\section{H1. Managerial political ties have a positive relationship with firm performance.}

Although previous studies did not provide a clear linkage between managerial political ties and institutional supports, most of them indirectly mentioned a potential relationship. Institutional support assists the government's administrative process (Haiyang \& Atuahene-Gima, 2001). Adopting the resource-based view, McWilliams et al. (2002) and Pruthi and Wright (2017) indicate that ventures which can extract potential resources from political ties can eventually improve their profitability. Often, prior studies separated resources and capabilities. Resources include tangible and intangible assets, and capabilities include the process and intangible properties of leveraging political resources (Dahan, 2005; Lawton et al., 2013). Both are considered valuable to firms because they enable them to recognize opportunities in a business environment. Besides scarce and essential resources (Wang and Lestari, 2013; Xin and Pearce, 1996), business ties with government agencies and officials result in various preferential treatments, such as investment and financing opportunities (Acquaah, 2007; V. Z. Chen et al., 2014; Haiyang \& Zhang, 2007; Kung \& Cheng, 2012; Peng \& Luo, 2000), government subsidies, bank loans and tax breaks (Chen et al., 2011; Hongbin et al., 2008). Furthermore, MNCs can influence regulatory policies and obtain the latest information regarding new governmental regulations (Acquaah, 2007; Hillman, 2005; Hillman et al., 2004; Lester et al., 2008; Sheng et al., 2011). More importantly, MNCs can also use these resources properly, in distinctive ways, to generate a competitive advantage (Lawton et al., 2013). Thus, we propose our second hypothesis:

\section{H2. Managerial political ties have a positive relationship with institutional support.}

According to previous studies, solid political connections result in legitimacy. For instance, Sheng et al. (2011) illustrate that firms with close ties have better legitimacy than ones without. Guo et al. (2014) highlighted two mechanisms that political officials use to create favourable conditions for legal compliance in business. The first one is a better understanding of institutional regulations, and the second one is firm legitimacy recognition through interpersonal relationships with administrative agencies. Additionally, Chen et al. (2016) uncovered that legitimacy has a crucial relationship with performance and mediates the relationship between government ties and firm performance. Therefore, we propose our third hypothesis:

\section{H3. Managerial political ties have a positive relationship with regulatory legitimacy.}

As mentioned above, managerial ties with government officials and agencies help firms not only to create but also to recognize opportunities in the business environment. Political ties provide firms with greater access to tangible and intangible resources, which can be integrated using various methods to improve their current situation and create a new market. Moreover, retrieving up-to-date information enables firms to catch up with new market demands (Li and Zhou, 2010) and understand important regulatory changes (Guo et al., 2014). The ability to mobilize a government agency to influence regulatory policies is another great contributor to the opportunity recognition process (Hillman et al., 2004; Rao et al., 2000). In brief, since government connections are beneficial for recognizing opportunities, we propose our fourth hypothesis:

\section{H. Managerial political ties have a positive relationship with opportunity recognition.}

\subsection{Institutional support and firm performance}

Local governments provide institutional supports to firms that contribute positively to the firms' operational performance and are likely to lead to their success (Haiyang \& Atuahene-Gima, 2001). Nguyen et al. (2017) conducted surveys in 2005, 2007, 2011, 2013 and 2015 among representatives of small and medium manufacturing firms in Vietnam to examine the relationship between government support and firm financial performance. They find that government financial supports (tax exemptions, soft loans and investment incentives) have positive impacts on firms' financial performance. With the underdeveloped market mechanisms in emerging countries such as Vietnam, supporting programmes play an important role for businesses (Peng and Heath, 1996). According to Guo et al. (2014), one variation of institutional support are government policies that help ventures with more strategies and expanded business production through loans and the issuance of essential licenses. Institutional supports are also used as a tool to strengthen the effect of political ties on firm performance. In an empirical study of Brazil's 
auto-parts industry, Mesquita, Lazzarini, \& Cronin (2007) show that institutional support stimulates the effectiveness of interfirm connections and in turn drives to stronger performance. Moreover, in a recent study on both Chinese manufacturers and Indian manufacturers, Zhang et al. (2019) find that institutional support play a significant mediator in business and political ties only in China, which in turn lead to enhancing firm performance. Thus, we propose our fifth hypothesis:

\section{H. Institutional support is positively associated with firm performance.}

\subsection{Regulatory legitimacy and firm performance}

Regulatory legitimacy has been explored in numerous aspects and contexts. In previous studies, Rao et al. (2008) and Delmar and Shane (2004) show that legitimacy improves business resources and makes it easier for firms to acquire support from stakeholders and society as a whole, but it also helps decrease legal violations and dependence on market turbulence. Firms' compliance with the law can be accomplished through absolute compliance with the current institutional settings (Suchman, 1995). Similarly, a firm is considered to have legitimacy only when it respects and adheres to the societal norms, values and principles (Deephouse \& Carter, 2005). Therefore, developing a legitimate framework is vital. It can be treated as a resource and capability for gaining support from other stakeholders in the firm's focal net (Guo et al., 2014). Along with operations and the business process, legitimacy not only enhances a firm's ability to survive in the market (DiMaggio and Powell, 1983) but also improves firm performance by mitigating the liability of newness (Singh et al., 1986) or venture disbanding (Delmar and Shane, 2004). This is especially essential for new MNCs entering into harsh competition with a long-established organization in a new market. Last but not least, having the appropriate, legitimate framework allows for seizing crucial resources (He \& Baruch, 2010; Zott \& Huy, 2007) and facilitates organizing activities (Delmar and Shane, 2004). Therefore, we propose our sixth hypothesis:

\section{H. Regulatory legitimacy is positively associated with firm performance.}

\subsection{Opportunity recognition and firm performance}

Shane and Venkataraman (2000) defined a business opportunity as the circumstance where a company's products are sold to the market with revenue exceeding cost. This type of opportunity is becoming increasingly important in the highly competitive markets of transitional economies, such as Vietnam. Firms benefit from being able to recognize and seize an opportunity to operate by leveraging their resources more efficiently (Ardichvili et al., 2003). This is also a central issue in examining entrepreneurship (Eckhardt and Shane, 2003; Short et al., 2010). Moreover, it is obvious that connections to political officials contribute significantly to recognizing opportunities. Therefore, each firm should be able to realize and take advantage of changes in state policies as soon as possible in order to create such favourable opportunities to learn about underrated, unexplored market demands and fulfil their needs. Thus, we propose our seventh hypothesis:

\section{$\boldsymbol{H}_{7 .}$ Opportunity recognition is positively associated with firm performance.}

\subsection{Training activities and firm performance}

The significance of training activities emerged through our qualitative process. Local governments and officials often conduct training as a new construct that might affect the experience. Therefore, the term of "training activities" is used outside the context of human resources here because it refers to the circumstance where the government provides training in an attempt to assist foreign and domestic companies (Nguyen et al., 2016). Twenty-four in-depth interviews with managers from different countries yielded considerable useful information about the role of local government agencies in their home countries with regard to training activities for low-paid sectors. For instance, government agencies generate numerous policy tensions to help the youth access adequate career advice. In addition, the local government strives to keep up with the changing work structures to ensure that the interests of trainees are responsive to the labour market opportunities. Therefore, in this context, this study constituted an attempt to explore whether the new construct of training activities has any relationship with firm performance. The training projects consist of different activities that are relevant to the regulatory policies for new enterprises and updates to regulations for long-established companies. Vietnam has an administrative procedure that is considered long and complex. As the regulations are constantly changing, and the requirements, such as operations safety, environmental protection and fire prevention training, are becoming stricter, we propose that this is an indispensable factor for firm performance and operations in this market. However, some controversies regarding this factor remain. For example, on one hand, a review of the Binh Duong Statistics Office Report and other indicators (e.g. the Provincial Competitive Index) shows that governmental training activities are not at a satisfactory level for certain industries. Most companies are not satisfied with the current training programmes and sometimes even consider them useless and time consuming. Besides, the shortage of lectures on new policies, market information or legal issues, all of which are of paramount importance to MNCs, is a huge gap in these programmes. On the other hand, although the state authorities admit to their lack of up-to-date industry information, practical applications or low- 
quality infrastructures in some provinces, they also claim that part of the reason for this is because the firms or workers participating in training courses just want to be granted certificates, and indeed most of them participate just to be qualified.

Moreover, the low number of participants in training courses reflects their level of interest and concern about the training content. Consequently, if the feedback on programmes is not evaluated appropriately, this leads to many difficulties in organizing the proper classes for firms in the future. However, the authorities are doing their best to diversify training methods and narrowing down training content to fit with each industry and be more practical. One main difference between training activities and the previous mechanisms is that although MNCs' ability to recognize opportunities, compliance with the institutional system and support of the government are required for other mediating factors, training activities are solely controlled by the government. Thus, we intended for the study to establish a direct influence of training activities on firm performance rather than digging deeper into the relationship between political links and training activities. Consequently, we propose the eighth hypothesis:

\section{$\boldsymbol{H}_{8 .}$ Governmental training activities are positively related to firm performance.}

Fig. 1 illustrates the research model with hypothesis development.

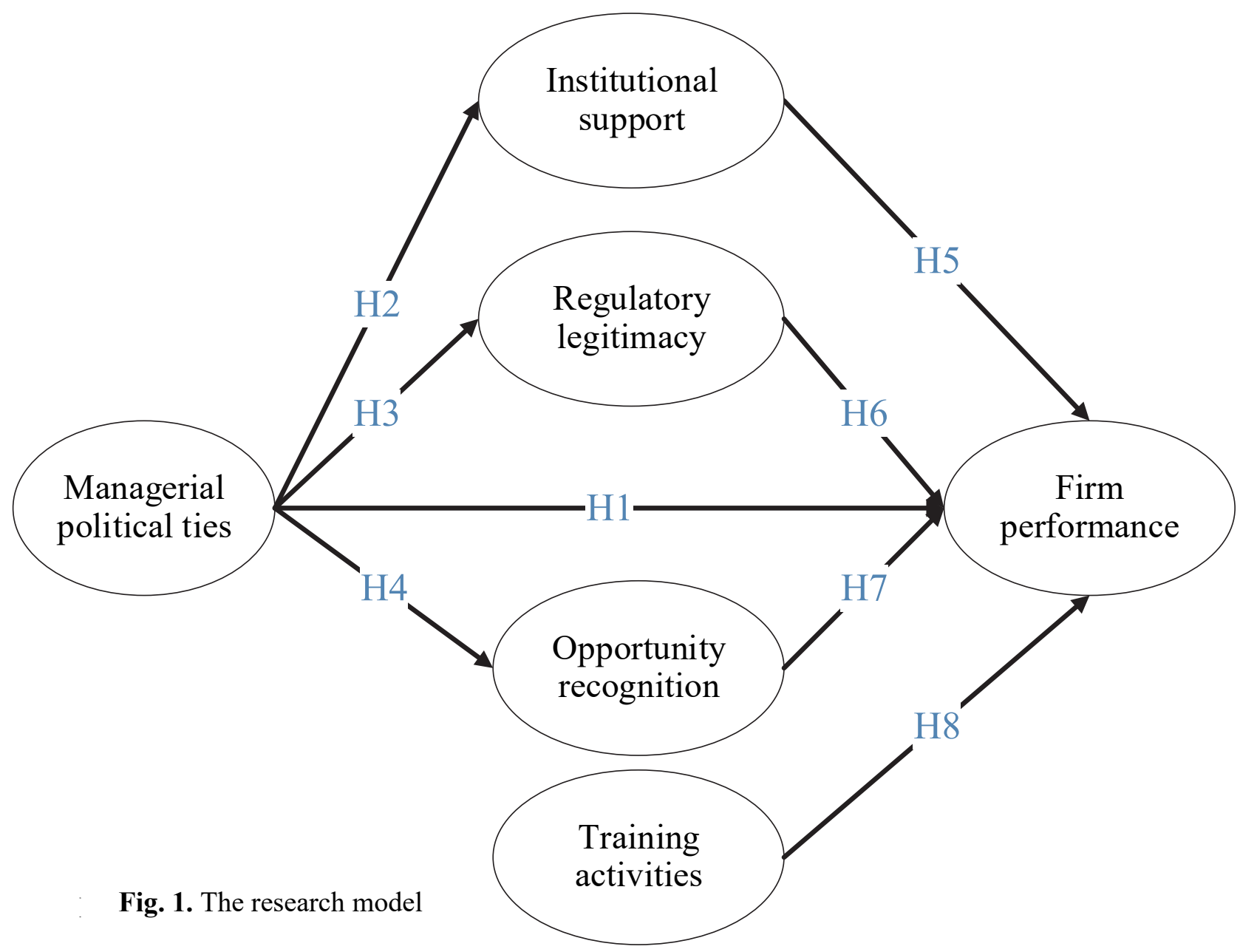

\section{Methodology}

\subsection{Research methodology}

Based on the research context and literature review, we deployed a mixed-methods approach in this study. This is because an integrated approach can enable a deeper investigation and wider range of the research by incorporating various methods of enquiry, which helps to generate more comprehensive results (Creswell, 2013). The combination of qualitative and quantitative data, known as triangulation, would allow for thoroughly illustrating the important role of governmental management in the Vietnamese context. The managerial procedure varies across countries; thus, under this approach, the qualitative stage focused 
on defining the constructs and building the measurement for newly developed constructs. Then the quantitative phase validated the factors and established the relationships among the variables (Saunders et al., 2009).

\subsection{Data collection}

As a preliminary step, in-depth interviews were conducted with executives and managers of MNCs in all five cities and provinces because "in-depth interviews are recommended for uncovering valuable insights, experiences, and perspectives that are difficult to obtain through other research techniques" (Creswell and Clark, 2007; Zhao and Ha-Brookshire, 2018). Twenty-four in-depth interviews with representatives of MNCs and eight group discussions with government officials were conducted. These interviews were aimed at identifying the issues that firms face and evaluating the industry representatives' recommendations in light of the current situation of governmental management in cities and provinces. The questionnaire included confirming mechanism factors of political ties found in prior studies and exploring distinctive new constructs in the five locations. All participants were managers or representatives of different departments of MNCs, and each interview lasted between one and two hours. The interviewers were fluent in both English and Vietnamese; therefore, the language used in each discussion depended on the participants' preference. Furthermore, as suggested by the grounded theory of Long et al. (2006), the study employed the theoretical sampling method. Particularly, after the interviews with representatives of the MNCs, the research team spoke with experts and officials from government agencies to clarify the business managers' ideas and opinions. The point of this was to avoid research bias and ensure objectivity. Structured questionnaires were given to managers of MNCs in Ho Chi Minh City, and four provinces including Binh Duong, Long An, Ben Tre and Tien Giang, with the help of experts in governmental agencies, managers in industrial zones, the Department of Planning and Investment, the Departments of Industry and Trade, and the Departments of Science and Technology. Among the 450 distributed questionnaires, 252 were returned, yielding a 56\% response rate. After eliminating 138 surveys that had been filled in incorrectly, were missing valuable information or did not meet the sample criteria, the final data set included 114 valid, usable items, reflecting a final response rate of 25.3\%, which is normal for this type of research (Baum et al., 2001; Moreno \& Casillas, 2008; Wiklund \& Shepherd, 2005; Zahra \& Garvis, 2000). The questionnaires contained two main sections. The first section sought general information about the FDI firms and the second section concentrated on managers' evaluations of the relevance of governmental support to business operations. The information of the surveyed companies is summarized as follows:

\section{Table 1}

Company's information

\begin{tabular}{|c|c|c|c|}
\hline \multicolumn{2}{|r|}{ Company information } & \multirow{2}{*}{$\begin{array}{c}\text { Frequency } \\
19\end{array}$} & \multirow{2}{*}{$\begin{array}{c}\text { Percentage } \\
16.7 \%\end{array}$} \\
\hline Industry & Textile and garment & & \\
\hline & Furniture design and manufacture & 8 & $7 \%$ \\
\hline & Stainless steel manufacture & 9 & $7.8 \%$ \\
\hline & Electronic component manufacture & 13 & $11.4 \%$ \\
\hline & Processed food manufacture & 7 & $9 \%$ \\
\hline & Plastic manufacture & 24 & $6.14 \%$ \\
\hline & Other & 34 & $29.8 \%$ \\
\hline \multirow[t]{6}{*}{ Country of origin } & America & 6 & $5.3 \%$ \\
\hline & Japan & 7 & $6.14 \%$ \\
\hline & Korea & 23 & $20.2 \%$ \\
\hline & Taiwan & 43 & $37.7 \%$ \\
\hline & Singapore & 10 & $8.8 \%$ \\
\hline & Other & 25 & $21.9 \%$ \\
\hline \multirow[t]{3}{*}{ Surveyed respondents } & $\mathrm{CEO}$ & 22 & $19.3 \%$ \\
\hline & $\mathrm{CFO}$ & 11 & $9.6 \%$ \\
\hline & Others & 81 & $71.1 \%$ \\
\hline
\end{tabular}

\subsection{Measures}

Using the results of the qualitative analysis, combined with the theoretical background of previous studies relating to the role of state management, the authors developed the research model, which consisted of two independent factors and three mediators. Standardized scales for these factors were also established to prepare for the primary fieldwork as the basis for the quantitative analysis. The provincial governments' supporting programmes for short training activities were newly discovered during our qualitative study; they had not been investigated deeply in prior studies and, consequently, no well-constructed measurement scale had been established. The training activities evaluate the effectiveness of governmental training activities on firm performance. Employing the grounded theory method of coding, which ensures the reliability of the construct and theme creation, we followed three steps - namely, open coding, axial coding and selective coding - to formulate the scales for this variable. Six of the most repeated terms related to training activities offered by provincial governments were utilized: (1) fire protection in the workplace (fire detection, warning systems and firefighting equipment with maintenance and testing); (2) labour safety (occupational health and safety awareness training focusing on the health and safety rights and responsibilities of workers, supervisors and employers); (3) introduction of new policies for foreign investors; (4) information on commitment to 
trade and market information; (5) announcement of the transparency of information and policies related to business; and (6) business seminars and business meetings. In total, there were six constructs in the conceptual framework: the two independent constructs of political ties and training activities; the three mediators of institutional support, regulatory legitimacy and opportunity recognition; and a dependent construct of firm performance. All statements in the questionnaire used a 5-point Likert-type scale ranging from $1=$ "Strongly disagree" to $5=$ "Strongly agree". Appendix A Table A1 described the measurement scale. Consequently, we used partial least squares structural equation modelling (PLS-SEM) in SmartPLS 3.0 M3 to analyse the data and test the model and hypotheses. "As a multivariate analysis technique, PLS enables researchers to examine latent and manifest variables simultaneously" (Mennens et al., 2018). PLS-SEM was suitable for this study for various reasons. First, it is an appropriate tool for analysing a structural model with a small sample size and containing both reflective and formative constructs (Chin, 1998; Hair et al., 2011; Hair et al., 2012; Henseler et al., 2009). Moreover, using the "ten times rule of thumb" of Barclay et al. (1995) and Hair et al. (2013), a "minimum sample size should be equal to the larger of 10 times the largest number of formative indicators used to measure a single construct, or 10 times the largest number of structural paths directed at a particular construct in the structural model". Therefore, the sample size was fully adaptable to PLS-SEM. Second, when dealing with a rather complex model and relatively few well-established kinds of literature, PLS-SEM is a suitable choice (Gefen et al., 2000; Peng and Lai, 2012). Third, considering the absence of distributional assumptions in some social science studies, the use of PLS-SEM is an advantage ( Hair et al., 2019). In sum, we chose PLS-SEM for the study owing to the limited prior literature, small sample size and use of a complex construct (Hair et al., 2014).

\section{Results}

\subsection{Data analysis}

Exploratory factor analysis (EFA) with principle axis factoring and promax rotation was performed on the indicators of the reflexive latent variables to preliminarily assess the factors' unidimensionality. The loadings of these variables on the intended factors were above 0.5, indicating good performance of the variables in their assigned blocks (Hair et al., 2010). In addition to the primary function of EFA, possible common method bias was tested for using Harman's (1976) single factor test. Constraining all variables into one factor showed that there was no general factor accounting for the majority of variance (the highest factor accounted for approximately $39 \%$ of the variance, far less than $50 \%$ ). Thus, it could be concluded that the data set did not suffer from common method bias. The structural model was then investigated via PLS-SEM. This study used various tests to qualify the structural analysis. Cronbach's alpha of each construct was evaluated, and the results were all greater than 0.7, assuring the construct reliability. Additionally, the composite reliability was used to test whether the extracted factor possessed high internal consistency (Bagozzi, 1981; Hair et al., 2010). According to the results, all values were above 0.7, satisfying the preferable threshold of Hair Jr et al. (2014) and Gefen et al. (2000). Convergent validity and discriminant validity were then evaluated. For convergent validity, which specifies that the latent factors should be well presented by their observed variables, the average variance extracted (AVE) must be higher than 0.5. In Table 1, all AVEs are above the threshold, ensuring convergent validity (Fornell and Larcker, 1981; Hair et al., 2010) and indicating that each construct explains 50\% or more of the variance of items making up the construct. Moreover, most of the outer loadings were higher than 0.7 , sufficiently accounting for more than 50\% of their latent constructs (Chin, 1998; Hair et al., 2010) and satisfying the theoretical requirement of Henseler et al. (2012), except for RL1 (0.639), TA5 (0.678) and FP3 (0.695). However, Hair et al. (2013) suggested removing outer loadings within the range of 0.4 to 0.7 when their removal can increase the composite reliability such that it exceeds the suggested threshold value; in this case, removing the above three items led to a decrease in TA4 from 0.730 to 0.68 . Therefore, all outer loadings were retained.

For discriminant validity, which demonstrates the statistical difference between two constructs, cross-loadings were evaluated first. Specifically, the outer loadings of all items within a construct should be higher than their cross-loadings (i.e. correlation) with another construct (Hair et al., 2013). Table 2 shows that all cross-loadings satisfy the requirement, which indicates the establishment of discriminant validity. Next, the Fornell-Larcker criterion was assessed. Previous authors suggested that within the criterion, the square root of the AVE of a factor is higher than the highest correlation coefficient of the factor with other factors, or the AVE is higher than the square of the highest coefficient correlation (Fornell \& Larcker, 1981; Hair et al., 2010). Table 3 summarizes the discriminant validity test results of the factor correlation matrix, and it can be seen that all identified constructs satisfy the requirement. This type of validity not only emphasizes the differences between factors but also indicates that a single observed variable highly loads on a single factor (or no cross-loadings) (Hair et al., 2010). However, Henseler et al. (2015) illustrated that sometimes the performance of cross-loadings and the Fornell-Larcker criterion do not fully detect discriminant validity problems. More specifically, cross-loadings fail to point out a lack of discriminant validity when the correlation between two constructs is perfect, or the Fornell-Larcker criterion's performance is poor when item loadings within a construct only differ slightly (e.g. ranging between 0.65 and 0.85 ). Therefore, to resolve this issue, this study utilized heterotrait-monotrait ratios (HTMT), which is the mean value of all item correlations across constructs (i.e. heterotraitheteromethod correlations) relative to the (geometric) mean of the average correlations for items measuring the same construct 
A. T. H. Nguyen et al. /Accounting 6 (2020)

(i.e. monotrait-heteromethod correlations). All HTMT values in Table 4 are below the threshold of 0.85 (Clark and Watson, 1995; Kline, 2011), except for the linkage between training activities and opportunity recognition (0.855). However, this value is also acceptable when considering a threshold of 0.9 for a path model with conceptually similar constructs (Henseler et al., 2015). Therefore, overall, the discriminant validity of this model is well confirmed.

Table 2

Construct reliability and convergent validity analysis

\begin{tabular}{|c|c|c|c|c|c|c|}
\hline Observed variable & Mean & $S D$ & Factor loading & $A V E$ & $C R$ & Cronbach's alpha \\
\hline Managerial political ties (MPT) & & & & .689 & .869 & .776 \\
\hline MPT1 & 3.274 & 1.066 & .860 & & & \\
\hline MPT2 & 3.274 & .884 & .818 & & & \\
\hline MPT3 & 3.601 & .991 & .810 & & & \\
\hline Institutional support (IS) & & & & .625 & .869 & .798 \\
\hline IS1 & 3.46 & 1.122 & .853 & & & \\
\hline IS2 & 3.566 & 1.003 & .744 & & & \\
\hline IS3 & 3.64 & .913 & .848 & & & \\
\hline IS4 & 3.40 & 1.142 & .707 & & & \\
\hline Regulatory legitimacy (RL) & & & & .563 & .836 & .739 \\
\hline RL1 & 3.04 & 1.004 & .639 & & & \\
\hline RL2 & 3.24 & 1.042 & .760 & & & \\
\hline RL3 & 3.52 & .933 & .842 & & & \\
\hline RL4 & 3.13 & 1.000 & .747 & & & \\
\hline Training activities (TA) & & & & .612 & .903 & .870 \\
\hline TA1 & 3.68 & 1.125 & .871 & & & \\
\hline TA2 & 3.82 & .992 & .855 & & & \\
\hline TA3 & 3.78 & 1.028 & .829 & & & \\
\hline TA4 & 3.63 & .943 & .730 & & & \\
\hline TA5 & 3.66 & .976 & .678 & & & \\
\hline TA6 & 3.554 & 1.125 & .707 & & & \\
\hline Opportunity recognition (OR) & & & & .692 & .899 & .849 \\
\hline OR1 & 3.47 & 1.099 & .880 & & & \\
\hline OR2 & 3.67 & .965 & .813 & & & \\
\hline OR3 & 3.65 & .995 & .889 & & & \\
\hline OR4 & 3.55 & .978 & .735 & & & \\
\hline Firm performance $(\mathrm{FP})$ & & & & .642 & .915 & .887 \\
\hline FP1 & 3.58 & 1.151 & .850 & & & \\
\hline FP2 & 3.77 & .987 & .847 & & & \\
\hline FP3 & 3.79 & .964 & .695 & & & \\
\hline FP4 & 3.681 & 1.032 & .725 & & & \\
\hline FP5 & 3.88 & 1.098 & .851 & & & \\
\hline FP6 & 3.87 & .991 & .824 & & & \\
\hline
\end{tabular}

Table 3

Discriminant validity (Formell and Lacker's criterion)

\begin{tabular}{|c|c|c|c|c|c|c|}
\hline Latent variable & FP & IS & $\mathrm{RL}$ & OR & MPT & TA \\
\hline Firm performance (FP) & 0.801 & & & & & \\
\hline Institutional support (IS) & 0.471 & 0.791 & & & & \\
\hline Regulatory legitimacy (RL) & 0.556 & 0.356 & 0.750 & & & \\
\hline Opportunity recognition (OR) & 0.740 & 0.542 & 0.476 & 0.832 & & \\
\hline Managerial political ties (MPT) & 0.441 & 0.467 & 0.387 & 0.572 & 0.830 & \\
\hline Training activities (TA) & 0.723 & 0.680 & 0.459 & 0.741 & 0.532 & 0.782 \\
\hline
\end{tabular}

Table 4

Discriminant validity (Heterotrait-Monotrait ratio of correlations)

\begin{tabular}{|c|c|c|c|c|c|c|}
\hline Latent variable & FP & IS & RL & OR & MTP & TA \\
\hline FP & \multicolumn{6}{|c|}{ Criteria $\leq 0.85$} \\
\hline IS & 0.549 & & & & & \\
\hline RL & 0.666 & 0.448 & & & & \\
\hline OR & 0.842 & 0.641 & 0.576 & & & \\
\hline MPT & 0.513 & 0.570 & 0.490 & 0.698 & & \\
\hline TA & 0.812 & 0.806 & 0.550 & 0.855 & 0.634 & \\
\hline
\end{tabular}

Initially, all independent variables were assessed for collinearity to ensure that the regression results were not biased. Hair et al. (2014) recommended that the variance inflation factor (VIF) be below 5. All independent factors (political ties, institutional 
support, regulatory legitimacy, opportunity recognition and training activity) have a VIF well below the required threshold. Thus, collinearity was not a substantial issue in the study. The hypotheses were tested using the nonparametric technique of bootstrapping 5,000 samples (Hair et al., 2014). First, the coefficient of determination $\left(\mathrm{R}^{2}\right)$ of the dependent construct was examined as a measurement for the model's explanatory power. According to Hair et al. (2011) and Henseler et al. (2009), in scholarly research, $\mathrm{R}^{2}$ levels of $0.25,05$ and 0.75 are considered to be weak, moderate and substantial, respectively. As Table 5 indicates, $65.7 \%$ of the variance of the dependent variable "firm performance" is explained by institutional support, regulatory legitimacy and opportunity recognition, indicating a moderate level. The variance explained in other constructs is $21.9 \%$ for institutional support, $32.8 \%$ for opportunity recognition and $15 \%$ for regulatory legitimacy. In addition, the study employed $\mathrm{Q}^{2}$ statistics to indicate the predictive relevance of the exogenous construct to the endogenous construct using the blindfolding procedure. According to Hair et al. (2019), as a rule of thumb, $\mathrm{Q}^{2}$ values above $0,0.25$ and 0.5 respectively depict small, medium and large predictive relevance of the PLS path model. Therefore, a result of 0.392 for firm performance demonstrated medium predictive relevance. Next, the path coefficient was tested to evaluate the significance levels of the hypothesized relationships. Table 5, which displays the final PLS-SEM results after running bootstrap, reveals that six out of eight hypotheses are supported with a positive value of path coefficient, a p-value below 0.05 and t-value above 1.96 . The results show that political ties significantly affect institutional support, regulatory legitimacy and opportunity recognition. However, only two of these eventually bear substantial effects on firm performance: the effect of opportunity recognition on firm performance is the strongest $(\beta=0.414)$, followed by a lower effect of regulatory legitimacy on firm performance $(\beta=0.227)$. Furthermore, government support via training activities has a quite strong, positive impact on firm performance $(\beta=0.393)$. Nevertheless, governmental, institutional support and, more importantly, managerial political ties have no significant impact on firm performance at all.

\section{Table 5}

Estimated results

\begin{tabular}{|c|c|c|c|c|c|}
\hline Hypothesis & Path & Estimates & P-value & Significant level & Results \\
\hline H1 & $\mathrm{MTP} \rightarrow \mathrm{FP}$ & -0.058 & 0.514 & - & Rejected \\
\hline $\mathrm{H} 2$ & MTP $\rightarrow$ IS & 0.467 & 0.000 & $* * *$ & Accepted \\
\hline H3 & $\mathrm{MTP} \rightarrow \mathrm{RL}$ & 0.387 & 0.000 & $* * *$ & Accepted \\
\hline $\mathrm{H} 4$ & $\mathrm{MTP} \rightarrow \mathrm{OR}$ & 0.572 & 0.000 & $* * *$ & Accepted \\
\hline H5 & $\mathrm{IS} \rightarrow \mathrm{FP}$ & -0.075 & 0.355 & - & Rejected \\
\hline H6 & $\mathrm{RL} \rightarrow \mathrm{FP}$ & 0.227 & 0.002 & $* *$ & Accepted \\
\hline $\mathrm{H} 7$ & $\mathrm{OR} \rightarrow \mathrm{FP}$ & 0.414 & 0.000 & $* * *$ & Accepted \\
\hline $\mathrm{H} 8$ & $\mathrm{TA} \rightarrow \mathrm{FP}$ & 0.393 & 0.000 & $* * *$ & Accepted \\
\hline
\end{tabular}

\subsection{Discussions}

The above analysis evinces that a weak correlation exists between managerial political ties and firm performance. According to Okhmatovskiy (2010), the ties are heavily context related; under the reported circumstances, no direct relationship exists between such ties and business performance. This finding was not consistent with the previous results (Chen et al., 2016; Guo et al., 2014; Li and Zhou, 2010; Peng and Luo, 2000; Sheng et al., 2011). However, it was consistent with the result of Sami, Rahnavard, \& Alavi Tabar (2019). In addition, political ties affect firm performance through different market mechanisms. In other words, managerial political ties showed significant indirect correlations with firm performance through regulatory legitimacy and opportunity recognition. This result was supported by the in-depth interviews, which means that establishing connections with government officials and their agencies can result in easier access to different policies and asymmetric information to support foreign companies. Moreover, MNCs can receive new regulatory policies in advance or lobby to launch new governmental regulations (Acquaah, 2007; Hillman, 2005; Hillman et al., 2004; Lester et al., 2008; Sheng et al., 2011). They can also utilize these resources, in distinctive approaches, to create a competitive advantage (Lawton et al., 2013). The finding of the supported H4 was consistent with the results of (Hillman et al., 2004; Rao et al., 2000). Throughout the governmental ties, foreign companies recognize and generate business opportunities for their business in terms of new potential markets, assessment of tangible and intangible resources, tax incentive holidays and so on. In contrast with the previous results (Mesquita, Lazzarini, \& Cronin, 2007; Guo et al., 2014), this study found no significant relationship between institutional support and firm performance. However, it is in line with the finding of Indian manufacturers from Zhang et al. (2019). Although managerial political ties did provide firms with various forms of institutional support, including policy implementation and license authorization. The relationship between opportunity recognition and firm performance was confirmed in this study, which is consistent with the research result of Guo et al. (2014), and proved to be the strongest among all. In other words, communicating with government officials to obtain new information and industry updates can provide a company with numerous opportunities. In the qualitative phase of this study, through in-depth interviews, many firms shared that they have found various industry opportunities regarding new customer demand, new markets or more innovative processes, and they were planning to capture such great opportunities shortly. 
Lastly, the path analysis illustrated the positive relationships between managerial political ties, regulatory legitimacy and firm performance. The impact of political connection on firm legitimacy was the second strongest, revealing that maintaining important governmental connections facilitates a firm's legitimacy process. Moreover, in Vietnam, there are currently numerous loopholes in the laws and regulations, and there is a lack of transparency. This explains how legality created a stable environment for FDI businesses to develop. However, this result is not consistent with the findings of Gou et al. (2014), who identified no significant impact of regulatory legitimacy on firm performance in China. From this point of view, the study confirms that in the Vietnamese context, regulatory legitimacy is considered to be as important a mechanism as opportunity recognition in terms of mediating the relationship between managerial political ties and firm performance. It implies that legitimacy improves business resources and makes it easier for firms to acquire support from stakeholders and society as a whole, but it also helps decrease legal violations and dependence on market turbulence (Rao et al., 2008; Delmar and Shane, 2004). It is also important to mention the impact of training activities on firm performance. Training activities still benefit MNCs' business performance in various ways. As partly represented in the qualitative phase, many practitioners admitted that the training programmes have improved considerably and become more up-to-date over time to fit the industry environment as well as to become more satisfactory and practical for firms. Furthermore, as the quantitative part of the study evinced, most firms confirmed the effectiveness of fire protection and labour safety training programmes or business seminars and meetings, etc. Overall, it is logical to infer that governmental training programmes are important for these firms.

\section{Conclusion and recommendations}

The findings of this study provide two interesting implications for MNCs working in Vietnam's emerging market in general and in the five examined locations in particular. First, close connections with political leaders provided more business opportunity recognition for firms, which eventually led to an increase in firm performance. As shown in the literature, this information is crucial for the current operation of a firm because, if integrated properly, it can create a new competitive advantage that boosts the firm's efficiency. Thus, gathering the data and completing the documentation to support capital investments and expansion may not be the only ways in which to seize opportunities. Finding sources of appropriate workforce education and training, identifying opportunities to improve current production processes and selecting vendors and suppliers for new machinery, computers and software are examples. In addition, engagement with governmental agencies can enhance a firm's legitimacy. This is extremely important in emerging markets because the current law lacks consistency and transparency, and the administrative procedures are complex and time-consuming. Thus, government ties can improve firm performance by enabling a firm to mobilize other stakeholders (especially those with power, like governmental agencies), mitigating the harmful effect of the "liability of newness" or facilitating other activities. In brief, relationship development is the key activity on which MNCs should focus. Having good relationships with administrative agencies can benefit a firm in terms of its performance through various mechanisms, broadly defined as opportunity recognition and regulatory legitimacy.

\subsection{Recommendations for Cities' and Provinces' Governmental Management}

The government must focus on increasing the quality of FDI to remain competitive. In addition to local firms, the government needs to focus on supporting foreign firms to move up the value chain and benefit from FDI spillovers, which are still limited in Vietnam. According to Smruti (2015), local firms depend on their absorptive capacity and benefit from vertical foreign presence. The greater the focus and size of the local market, the more profitability overflows from a foreign presence. Regarding institutional support, the application of information technology in management and administrative procedures has not been implemented synchronously, and there is a lack of coordination between state administrative agencies in addressing the issues of investors. Second, efforts to improve administrative procedures remain unaddressed and lead to many difficulties in operations. Technological infrastructure is underdeveloped and this has resulted in many negative outcomes in the performance of MNCs. The study revealed that these companies have overcome these drawbacks by having good connections to the network of political leaders at different levels. However, we think that some recommendations should also be directed towards governmental agencies. Arguably, the government should actively address these problems instead of forcing them on the companies as it may have a serious impact on the cities' and provinces' investment environment and hinder FDI in the provinces. However, the five locations remain aware that the increase in foreign investment has contributed positively to socioeconomic development. Lastly, previous studies showed that political ties have some negative aspects (Warren et al., 2004; Zhou et al., 2014). With the aim of supporting and reinforcing strategic planning, the study boldly suggests several orientations for the provinces.

\subsection{Improvement of Technological infrastructure}

Government agencies in the five locations should consider building synchronous infrastructure. In particular, local governments should avoid focusing solely on infrastructure development in the new industrial parks and also make appropriate investments in renovating and upgrading existing utility infrastructure. Additionally, the provinces must reconsider the plan for identifying urban areas to adjust appropriate land rent in the industrial parks, as the land rental fees are higher in urban industrial parks than 
in rural areas. Therefore, the local governments should develop industrial clusters according to professional specialty to take advantage of the cost reduction and promotion of competitive advantage through reciprocal supply chains. This would be a corrective method for institutional support in terms of resource (land) allocation.

\subsection{Administrative procedures}

Government agencies should consider constantly reforming administrative procedures towards the construction of e-government services. The interview results show that firms in the five regions experienced a breakthrough in administrative reform and policy development. Information on the innovation of policies and administrative procedures has been publicized in the media and on websites. However, the actual implementation of the policy is still not synchronized among departments. When dealing with administrative procedures, people and businesses still have to contact many state management agencies. The provinces should assign units to monitor and supervise the implementation of policies regarding administrative procedures in government agencies. At the same time, the urgent need to improve the implementation with clear and detailed instructions should be properly addressed. The ultimate goal is to build e-government. The central government should reconsider the process for granting investment certificates and certificates of business registration. The main role of the unification of investment certificate agencies and business registration agencies is to serve the interests of the business by implementing the principle that all businesses must register under the Enterprise Law to establish legal status before getting an investment certificate. However, the simplified procedure of having only one paper, a business registration permit, is considered the best option now. Another potential solution for implementing a perfect one-door policy is to redistribute the authority and responsibility to front agencies to resolve administrative processes. Lastly, enterprises providing public services should be established because they play an important role in the development of administrative services according to the advanced models in developed countries. These two solutions will enhance firm legitimacy in the transitional economy, where the law and regulations are not as transparent as in the countries of origin of MNCs, and the administrative procedures are complex. Further, institutional support in terms of intangible resources (policy) is embodied through this implementation.

\subsection{Training activities}

In training on policy, new market information played a crucial role in the development of current MNCs as well as the attraction of foreign investment in the provinces. Thus, training experts should pay more attention to these areas. Furthermore, short training courses in cultural awareness and global business skills are necessary to equip workers with the basic skills to work in MNCs. In addition, the workers should be armed with knowledge of their rights and responsibilities. Training programmes on international standards for safety and health should be carefully considered and implemented accordingly. Most of the company representatives had a favourable attitude towards these training activities. Last but not least, training fees should be identical to those of the neighbouring provinces.

\subsection{Limitations}

Although the study attempted to address current issues in the scientific research regarding governmental management in Vietnam, especially in the five locations of Ho Chi Minh City, Binh Duong, Long An, Ben Tre and Tien Giang, and depict a holistic picture of the effect of political ties on the performance of MNCs, the study had several limitations that future studies can consider. First, in any study utilizing primary data, common method bias is inevitable. In the present study, we tried to tackle the bias by using Harman's single factor test. However, future studies should carefully consider this issue. Second, the newly developed factors should be adopted with caution in studies conducted in different contexts. Although the practical significance of the constructs was assured through the qualitative analysis, the statistical significance should be re-examined in further studies. Third, the research could only consider five key economic zones in southern Vietnam. In the middle or northern regions of the country, the economic environment can be differences in facilities, infrastructure, the labour force, etc. Therefore, future researchers can consider examining key economic zones in various parts of Vietnam to ensure that the results are not biased to one specific region. In addition, if future researchers are capable of covering a broader population and reaching a larger sample size, different approaches and data analysis techniques can be employed to test the hypotheses and report any new findings.

\section{References}

Acquaah, M. (2007). Managerial social capital, strategic orientation, and organizational performance in an emerging economy. Strategic Management Journal, 28(12), 1235-1255. https://doi.org/10.1002/smj.632

Anwar, S., \& Nguyen, L. P. (2014). Is foreign direct investment productive? A case study of the regions of Vietnam. Journal of Business Research, 67(7), 1376-1387. https://doi.org/10.1016/j.jbusres.2013.08.015

Anwar, S., \& Sun, S. (2014). Heterogeneity and curvilinearity of FDI-related productivity spillovers in China's manufacturing 
sector. Economic Modelling, 41(August), 23-32. https://doi.org/10.1016/j.econmod.2014.03.021

Ardichvili, A., Cardozo, R., \& Ray, S. (2003). A theory of entrepreneurial opportunity identification and development. Journal of Business Venturing, 18(1), 105-123. https://doi.org/10.1016/S0883-9026(01)00068-4

Bagozzi, R. P. (1981). An examination of the validity of two models of attitude. Multivariate Behavioral Research, 16(3), 323359. https://doi.org/10.1207/s15327906mbr1603 4

Barclay, D., Higgins, C., \& Thompson, R. (1995). The partial least squares (PLS) approach to causal modeling: personal computer adoption and use as an illustration. Technology Studies, 2(2), 285-309.

Batjargal, B. (2003). Social capital and entrepreneurial performance in Russia: A longitudinal study. Organization Studies, 24(4), 535-556. https://doi.org/10.1177/0170840603024004002

Baum, J. A. C., \& Oliver, C. (1991). Institutional Linkages and Organizational Mortality. Administrative Science Quarterly, 36(2), 187-218. https://doi.org/10.2307/2393353

Bruton, G. D., Ahlstrom, D., \& Li, H. L. (2010). Institutional theory and entrepreneurship: Where are we now and where do we need to move in the future? Entrepreneurship: Theory and Practice, 34(3), 421-440. https://doi.org/10.1111/j.15406520.2010.00390.x

Chen, C. J. P., Li, Z., Su, X., \& Sun, Z. (2011). Rent-seeking incentives, corporate political connections, and the control structure of private firms: Chinese evidence. Journal of Corporate Finance, 17(2), 229-243. https://doi.org/10.1016/j.jcorpfin.2010.09.009

Chen, S. T., Haga, K. Y. A., \& Fong, C. M. (2016). The effects of institutional legitimacy, social capital, and government relationship on clustered firms' performance in emerging economies. Journal of Organizational Change Management, 29(4), 529-550. https://doi.org/10.1108/JOCM-11-2015-0211

Chen, V. Z., Li, J., Shapiro, D. M., \& Zhang, X. (2014). Ownership structure and innovation: An emerging market perspective. Asia Pacific Journal of Management, 31(1), 1-24. https://doi.org/10.1007/s10490-013-9357-5

Chin, W. W. (1998). The partial least squares approach for structural equation modeling. Modern Methods for Business Research, 295(2), 295-336. https://doi.org/10.1016/j.aap.2008.12.010

Choi, S. G., \& Johanson, J. (2012). Knowledge translation through expatriates in international knowledge transfer. International Business Review, 21(6), 1148-1157. https://doi.org/10.1016/j.ibusrev.2012.01.002

Clark, L. A., \& Watson, D. (1995). Constructing Validity: Basic Issues in Objective Scale Development The Centrality of Psychological Measurement. Psychological Assessment, 7(3), 309-319. https://doi.org/10.1037/1040-3590.7.3.309

Creswell, J. W. (2013). Research design: Qualitative, quantitative, and mixed methods approaches (3rd ed). In Research Design. Thousand Oaks: Sage publications. https://doi.org/10.1016/j.math.2010.09.003

Creswell, J. W., \& Clark, V. L. P. (2007). Designing and Conducting Mixed Methods Research. Thousand Oaks, CA: Sage. Sage publications. https://doi.org/10.1111/j.1753-6405.2007.00096.x

Dahan, N. (2005). A contribution to the conceptualization of political resources utilized in corporate political action. Journal of Public Affairs, 5(1), 43-54. https://doi.org/10.1002/pa.4

Deephouse, D. L., \& Carter, S. M. (2005). An examination of differences between organizational legitimacy and organizational reputation. Journal of Management Studies, 42(2), 329-360. https://doi.org/10.1111/j.1467-6486.2005.00499.x

Delmar, F., \& Shane, S. (2004). Legitimating first: Organizing activities and the survival of new ventures. Journal of Business Venturing, 19(3), 385-410. https://doi.org/10.1016/S0883-9026(03)00037-5

DiMaggio, P., \& Powell, W. (1983). The Iron Cage Revisited: Institutional Isomorphism and Collective Rationality in Organizational Fields Paul J. DiMaggio; Walter W. Powell. American Sociological Review, 48(2), 147-160.

Eckhardt, J. T., \& Shane, S. A. (2003). Opportunities and entrepreneurship. Journal of Management, 29(3), 333-349. https://doi.org/10.1016/S0149-2063(02)00225-8

F. Hair Jr, J., Sarstedt, M., Hopkins, L., \& G. Kuppelwieser, V. (2014). Partial least squares structural equation modeling (PLSSEM) An emerging tool in business research. European Business Review, 26(2), 106-121. https://doi.org/10.1108/EBR-102013-0128

Faccio, M. (2006). Connected Firms Politically. The American Economic Review, 96(1), 369-386.

Faccio, M. (2010). Differences between Politically Connected and Nonconnected Firms: A Cross-Country Analysis. Financial Management, 39(3), 905-928. https://doi.org/10.1111/j.1755-053X.2010.01099.x

Fornell, C. (1987). A second generation of multivariate analysis: Classification of methods and implications for marketing research. Review of Marketing (Houston M). Chicago, IL: American Marketing Association. https://doi.org/10.1017/CBO9781107415324.004

Fornell, C., \& Larcker, D. F. (1981). Evaluating Structural Equation Models with Unobservable Variables and Measurement Error. Journal of Marketing Research, 18(1), 39-50. https://doi.org/10.1177/002224378101800104

Gefen, D., Straub, D., \& Boudreau, M.-C. (2000). Structural Equation Modeling and Regression: Guidelines for Research Practice. Communications of the Association for Information Systems, 4(1), 1-77. https://doi.org/10.17705/1 cais.00407

Geletkanycz, M. A., \& Hambrick, D. C. (1997). The External Ties of Top Executives: Implications for Strategic Choice and Performance. Administrative Science Quarterly, 42(4), 654-681. https://doi.org/10.2307/2393653

Granovetter, M. (1985). Economic Action and Social Structure: The Problem of Embeddedness. American Journal of Sociology, 91(3), 481-510. 
Guo, H., Xu, E., \& Jacobs, M. (2014). Managerial political ties and firm performance during institutional transitions: An analysis of mediating mechanisms. Journal of Business Research, 67(2), 116-127. https://doi.org/10.1016/j.jbusres.2012.11.009

Hair, J., Black, W., Babin, B., \& Anderson, R. (2010). Multivariate Data Analysis a Global Perspective, Prentice Hall. Upper Saddle River, $N J$.

Hair, J. F., Hult, G. T. M., Ringle, C. M., \& Sarstedt, M. (2013). A Primer on Partial Least Squares Structural Equation Modeling. 2nd Ed. (2nd ed.). Thousand Oaks: Sage.

Hair, Joe F., Ringle, C. M., \& Sarstedt, M. (2011). PLS-SEM: Indeed a Silver Bullet. Journal of Marketing Theory and Practice, 19(2), 139-152. https://doi.org/10.2753/MTP1069-6679190202

Hair, Joe F., Sarstedt, M., Ringle, C. M., \& Mena, J. A. (2012). An assessment of the use of partial least squares structural equation modeling in marketing research. Journal of the Academy of Marketing Science, 40(3), 414-433.

Hair, Joseph F., Risher, J. J., Sarstedt, M., \& Ringle, C. M. (2019). When to use and how to report the results of PLS-SEM. European Business Review, 31(1), 2-24. https://doi.org/10.1108/EBR-11-2018-0203

He, H., \& Baruch, Y. (2010). Organizational identity and legitimacy under major environmental changes: Tales of two UK building societies. British Journal of Management, 21(1), 44-62. https://doi.org/10.1111/j.1467-8551.2009.00666.x

Henseler, J., Ringle, C. M., \& Sarstedt, M. (2012). Using Partial Least Squares Path Modeling in Advertising Research: Basic Concepts and Recent Issues. (E. Elgar, Ed.), Handbook of Research on International Advertising. Cheltenham, UK Northampton, MA, USA. https://doi.org/10.4337/9781848448582.00023

Henseler, J., Ringle, C. M., \& Sarstedt, M. (2015). A new criterion for assessing discriminant validity in variance-based structural equation modeling. Journal of the Academy of Marketing Science, 43(1), $115-135$. https://doi.org/10.1007/s11747-014-0403-8

Henseler, J., Ringle, C. M., \& Sinkovics, R. R. (2009). The use of partial least squares path modeling in international marketing. Advances in International Marketing, 20, 277-319. https://doi.org/10.1108/S1474-7979(2009)0000020014

Hillman, A. J. (2005). Politicians on the board of directors: Do connections affect the bottom line? Journal of Management, 31(3), 464-481. https://doi.org/10.1177/0149206304272187

Hillman, A. J., Keim, G. D., \& Schuler, D. (2004). Corporate political activity: A review and research agenda. Journal of Management, 30(6), 837-857. https://doi.org/10.1016/j.jm.2004.06.003

Hillman, A. J., Zardkoohi, A., \& Bierman, L. (1999). Corporate political strategies and firm performance: Indications of firmspecific benefits from personal service in the U.S. government. Strategic Management Journal, $20(1), 67-81$. https://doi.org/10.1002/(SICI)1097-0266(199901)20:1<67::AID-SMJ22>3.0.CO;2-T

Huynh, H. T. N., Nguyen, P. V., Trieu, H. D. X., \& Tran, K. T. (2019). Productivity Spillover from FDI to Domestic Firms across Six Regions in Vietnam. Emerging Markets Finance and Trade, Online, 1-17. https://doi.org/10.1080/1540496X.2018.1562892

Huynh, H. T. N., Tran, K. T., Nguyen, P. V., Le, N. T. T., \& Trieu, H. D. X. (2019). Estimating inward regional FDI spillover in Vietnamese manufacturing firms: Ownership structure and firm characteristics. Journal for Global Business Advancement, 12(4), 542-563. https://doi.org/10.1504/JGBA.2019.103316

Jayaram, J., \& Tan, K. C. (2010). Supply chain integration with third-party logistics providers. International Journal of Production Economics, 125(2), 262-271. https://doi.org/10.1016/j.ijpe.2010.02.014

Jiang, F., Guo, H., Wei, Z., \& Wang, D. (2018). The Fit between Managerial Ties and Resource Bundling Capabilities: Implications for Performance in Manufacturing Firms. IEEE Transactions on Engineering Management, 65(2), 216-226. https://doi.org/10.1109/TEM.2017.2785387

Johannisson, B., \& Monsted, M. (1998). Contextualizing Entrepreneurial Networking The Case of Scandinavia. International Studies of Management \& Organization, 27(3), 109-136.

Khwaja, A. I., \& Mian, A. (2005). Do lenders favor politically connected firms? Rent provision in an emerging financial market. Quarterly Journal of Economics, 120(4), 1371-1411. https://doi.org/10.1162/003355305775097524

Kline, R. (2011). Principles and practice of structural equation modeling (Third Edit). New York: The Guiford Press. https://doi.org/10.1038/156278a0

Kotabe, M., Jiang, C. X., \& Murray, J. Y. (2011). Managerial ties, knowledge acquisition, realized absorptive capacity and new product market performance of emerging multinational companies: A case of China. Journal of World Business, 46(2), 166176. https://doi.org/10.1016/j.jwb.2010.05.005

Kung, F. H., \& Cheng, C. L. (2012). The determinants of overseas listing decisions: Evidence from Chinese H-share companies. Asian Business and Management, 11(5), 591-613. https://doi.org/10.1057/abm.2012.24

Larson, A. (1991). Partner networks: Leveraging external ties to improve entrepreneurial performance. Journal of Business Venturing, 6(3), 173-188. https://doi.org/10.1016/0883-9026(91)90008-2

Lawton, T., Mcguire, S., \& Rajwani, T. (2013). Corporate Political Activity: A Literature Review and Research Agenda. International Journal of Management Reviews, 15(1), 86-105. https://doi.org/10.1111/j.1468-2370.2012.00337.x

Le, H. Q., \& Pomfret, R. (2011). Technology spillovers from foreign direct investment in Vietnam: Horizontal or vertical spillovers? Journal of the Asia Pacific Economy, 16(2), 183-201. https://doi.org/10.1080/13547860.2011.564746

Lester, R. H., Hillman, A., Zardkoohi, A., \& Cannella, A. A. (2008). Former government officials as outside directors: The role 
of human and social capital. Academy of Management Journal, $\quad 51(5), \quad 999-1013$. https://doi.org/10.5465/AMJ.2008.34789675

Li, Haiyang, \& Atuahene-Gima, K. (2001). Product innovation strategy and the performance of new technology ventures in China. Academy of Management Journal, 44(6), 1123-1134. https://doi.org/10.2307/3069392

Li, Haiyang, \& Zhang, V. (2007). The role of managers' political networking and functional experience in new venture performance: Evidence from China's transition economy. Strategic Management Journal, 28(8), $791-804$. https://doi.org/10.1002/smj.605

Li, Hongbin, Meng, L., Wang, Q., \& Zhou, L. A. (2008). Political connections, financing and firm performance: Evidence from Chinese private firms. Journal of Development Economics, 87(2), 283-299. https://doi.org/10.1016/j.jdeveco.2007.03.001

Li, J. J. (2005). The formation of managerial networks of foreign firms in China: The effects of strategic orientations. Asia Pacific Journal of Management, 22(4), 423-443. https://doi.org/10.1007/s10490-005-4118-8

Li, J. J., Zheng, K., \& Shao, A. T. (2009). Competitive position, managerial ties , and profitability of foreign firms in China : an interactive perspective. Journal of International Business Studies, 40(2), 339-352. https://doi.org/10.1057/jibs.2008.76

Li, J. J., \& Zhou, K. Z. (2010). How foreign firms achieve competitive advantage in the Chinese emerging economy: Managerial ties and market orientation. Journal of Business Research, 63(8), 856-862. https://doi.org/10.1016/j.jbusres.2009.06.011

Long, D. R., Strauss, A., \& Corbin, J. (2006). Basics of Qualitative Research: Grounded Theory Procedures and Techniques. Sage Publications. Newbury Park, CA. https://doi.org/10.2307/328955

Luo, Y. (2003). Industrial dynamics and managerial networking in an emerging market: the case of China. Strategic Management Journal, 24(13), 1315-1327. https://doi.org/10.1002/smj.363

Manolova, T. S., Manev, I. M., \& Gyoshev, B. S. (2014). Friends with money? Owner's financial network and new venture internationalization in a transition economy. International Small Business Journal: Researching Entrepreneurship, 32(8), 944-966. https://doi.org/10.1177/0266242613482482

McMillan, J., \& Woodruff, C. (1999). Interfirm relationships and informal credit in Vietnam. Quarterly Journal of Economics, 114(4), 1285-1320. https://doi.org/10.1162/003355399556278

McWilliams, A., Van Fleet, D. D., \& Cory, K. D. (2002). Raising rivals' costs through political strategy: An extension of resource-based theory. Journal of Management Studies, 39(5), 707-724. https://doi.org/10.1111/1467-6486.00308

Mennens, K., Van Gils, A., Odekerken-Schröder, G., \& Letterie, W. (2018). Exploring antecedents of service innovation performance in manufacturing SMEs. International Small Business Journal: Researching Entrepreneurship, 36(5), 500520. https://doi.org/10.1177/0266242617749687

Mesquita, L. F., Lazzarini, S. G., \& Cronin, P. (2007). Determinants of firm competitiveness in Latin American emerging economies: Evidence from Brazil's auto-parts industry. International Journal of Operations and Production Management, 27(5), 501-523. https://doi.org/10.1108/01443570710742384

Moreno, A. M., \& Casillas, J. C. (2008). Entrepreneurial orientation and growth of SMEs: A causal model. Entrepreneurship: Theory and Practice, 32(3), 507-528. https://doi.org/10.1111/j.1540-6520.2008.00238.x

Newman, C., Rand, J., Talbot, T., \& Tarp, F. (2015). Technology transfers, foreign investment and productivity spillovers. European Economic Review, 76(May), 168-187. https://doi.org/10.1016/j.euroecorev.2015.02.005

Nguyen, N. T. K. (2017). The Long Run and Short Run Impacts of Foreign Direct Investment and Export on Economic Growth of Vietnam. Asian Economic and Financial Review, 7(5), 519-527. https://doi.org/10.18488/journal.aefr.2017.75.519.527

Nguyen, T. V. (2005). Learning to trust: A study of interfirm trust dynamics in Vietnam. Journal of World Business, 40(2), 203221. https://doi.org/10.1016/j.jwb.2005.02.001

Okhmatovskiy, I. (2010). Performance implications of ties to the government and SOEs: A political embeddedness perspective. Journal of Management Studies, 47(6), 1020-1047. https://doi.org/10.1111/j.1467-6486.2009.00881.x

Park, S. H., \& Luo, Y. (2001). Guanxi and organizational dynamics: Organizational networking in Chinese firms. Strategic Management Journal, 22(5), 455-477. https://doi.org/10.1002/smj.167

Peng, D. X., \& Lai, F. (2012). Using partial least squares in operations management research: A practical guideline and summary of past research. Journal of Operations Management, 30(6), 467-480. https://doi.org/10.1016/j.jom.2012.06.002

Peng, M. W., \& Heath, P. S. (1996). The growth of the firm in planned economies in transition: Institutions, organizations, and strategic choice. Academy of Management Review, 21(2), 429-528. https://doi.org/10.5465/AMR.1996.9605060220

Peng, M. W., \& Luo, Y. (2000). Managerial ties and firm performance in a transition economy: The nature of a micro-macro link. Academy of Management Journal, 43(3), 486-501. https://doi.org/10.2307/1556406

Podolny, J. M., \& Page, K. L. (1998). Network Forms of Organization. Annual Review of Sociology, 24(1), 57-76. https://doi.org/10.1146/annurev.soc.24.1.57

Pollack, J. M., Coy, A. E., Green, J. D., \& Davis, J. L. (2015). Satisfaction, Investment, and Alternatives Predict Entrepreneurs' Networking Group Commitment and Subsequent Revenue Generation. Entrepreneurship: Theory and Practice, 39(4), 817837. https://doi.org/10.1111/etap.12075

Pruthi, S., \& Wright, M. (2017). Social Ties, Social Capital, and Recruiting Managers in Transnational Ventures. Journal of East-West Business, 23(2), 105-139. https://doi.org/10.1080/10669868.2016.1270247

Rao, H., Morrill, C., \& Zald, M. N. (2000). Power Plays: How Social Movements and Collective Action Create New Organizational Forms. Research in Organizational Behavior, 22, 237-281. https://doi.org/10.1016/s0191-3085(00)22007-8 
Rao, R. S., Chandy, R. K., \& Prabhu, J. C. (2008). The Fruits of Legitimacy:Why Some New Ventures Gain More from Innovation Than Others. Journal of Marketing, 72(4), 58-75. https://doi.org/10.1509/jmkg.72.4.58

Robert Baum, J., Locke, E. A., \& Smith, K. G. (2001). A multidimensional model of venture growth. Academy of Management Journal, 44(2), 292-303.

Sami, P., Rahnavard, F., \& Alavi Tabar, A. (2019). The effect of political and business ties on firm performance: The mediating role of product innovation. Management Research Review, 42(7), 778-796. https://doi.org/10.1108/MRR-12-2017-0439

Saunders, M., Lewis, P., \& Thornhill, A. (2009). Research Methods for Business Students Fifth edition. In Prentice Hall, Harlow, Essex. https://doi.org/10.1017/CBO9781107415324.004

Shane, S., \& Venkataraman, S. (2000). The promise of entrepreneurship as a field of research. Academy of Management Review, 25(1), 217-226. https://doi.org/10.1007/978-3-540-48543-8_8

Sheng, S., Zhou, K. Z., \& Li, J. J. (2011). The Effects of Business and Political Ties on Firm Performance : Evidence from China. Journal of Marketing, 75(1), 1-15. https://doi.org/10.1509/jm.75.1.1

Short, J. C., Ketchen, D. J., Shook, C. L., \& Ireland, R. D. (2010). The concept of “Opportunity” in entrepreneurship research: Past accomplishments and future challenges. Journal of Management, 36(1), 40-65. https://doi.org/10.1177/0149206309342746

Singh, J. V., Tucker, D. J., \& House, R. J. (1986). Organizational Legitimacy and the Liability of Newness. Administrative Science Quarterly, 171-193. https://doi.org/10.2307/2392787

Suchman, M. C. (1995). Managing Legitimacy: Strategic and Institutional Approaches. Academy of Management Review, 20(3), 571-610. https://doi.org/10.5465/amr.1995.9508080331

Thang, T. T., Pham, T. S. H., \& Barnes, B. R. (2016). Spatial Spillover Effects from Foreign Direct Investment in Vietnam. Journal of Development Studies, 52(10), 1431-1445. https://doi.org/10.1080/00220388.2016.1166205

Tihanyi, L., Aguilera, R. V., Heugens, P., van Essen, M., Sauerwald, S., Duran, P., \& Turturea, R. (2019). State Ownership and Political Connections. Journal of Management, 45(6), 2293-2321. https://doi.org/10.1177/0149206318822113

Tornikoski, E. T., \& Newbert, S. L. (2007). Exploring the determinants of organizational emergence: A legitimacy perspective. Journal of Business Venturing, 22(2), 311-335. https://doi.org/10.1016/j.jbusvent.2005.12.003

Tsang, E. W. (1998). Can guanxi be a source of sustained competitive advantage for doing business in China? Academy of Management Executive, 12(2), 64-73.

Vissa, B., \& Chacar, A. S. (2009). Leveraging ties: The contingent value of entrepreneurial teams' external advice networks on Indian software venture performance. Strategic Management Journal, 30(11), 1179-1191. https://doi.org/10.1002/smj.785

Wang, G., Jiang, X., Yuan, C.-H., \& Yi, Y.-Q. (2013). Managerial ties and firm performance in an emerging economy: Tests of the mediating and moderating effects. Asia Pacific Journal of Management, 30(2), 537-559. https://doi.org/10.1007/s10490-011-9254-8

Wang, K. J., \& Lestari, Y. D. (2013). Firm competencies on market entry success: Evidence from a high-tech industry in an emerging market. Journal of Business Research, 66(12), 2444-2450. https://doi.org/10.1016/j.jbusres.2013.05.033

Warren, D. E., Dunfee, T. W., \& Li, N. (2004). Social Exchange in China: The Double-Edged Sword of Guanxi. Journal of Business Ethics, 55(4), 353-370. https://doi.org/10.1007/s10551-004-1526-5

Wiklund, J., \& Shepherd, D. (2005). Entrepreneurial orientation and small business performance: A configurational approach. Journal of Business Venturing, 20(1), 71-91. https://doi.org/10.1016/j.jbusvent.2004.01.001

Xin, K. R., \& Pearce, J. L. (1996). Guanxi: Connections as substitutes for formal institutional support. The Academy of Management Journal, 39(6), 1641-1658.

Yu, X., Chen, Y., Nguyen, B., \& Zhang, W. (2014). Ties with government, strategic capability, and organizational ambidexterity: Evidence from China's information communication technology industry. Information Technology and Management, 15(2), 81-98. https://doi.org/10.1007/s10799-014-0175-3

Zahra, S. A., \& Garvis, D. M. (2000). International corporate entrepreneurship and firm performance: The moderating effect of international environmental hostility. Journal of Business Venturing, 15(5), 469-492. https://doi.org/10.1016/S08839026(99)00036-1

Zhang, M., Qi, Y., Wang, Z., Zhao, X., \& Pawar, K. S. (2019). Effects of business and political ties on product innovation performance: Evidence from China and India. Technovation, 80-81(February-March), 30-39. https://doi.org/10.1016/j.technovation.2018.12.002

Zhang, S., \& Li, X. (2008). Managerial ties, firm resources, and performance of cluster firms. Asia Pacific Journal of Management, 25(4), 615-633. https://doi.org/10.1007/s10490-008-9090-7

Zhao, L., \& Ha-brookshire, J. (2018). Importance of Guanxi in Chinese apparel new venture success : a mixed-method approach. Journal of Global Entrepreneurship Research, 8(13), 1-19. https://doi.org/10.1186/s40497-018-0099-1

Zhou, K. Z., Li, J. J., Sheng, S., \& Shao, A. T. (2014). The evolving role of managerial ties and firm capabilities in an emerging economy: evidence from China. Journal of the Academy of Marketing Science, 42(6), 581-595. https://doi.org/10.1007/s11747-014-0371-z

Zhu, Y. (2020). An interactive perspective of managers' functional experience and managerial ties of new ventures in transition economies. Technology Analysis \& Strategic Management, 32(3), 292-305. 
Zott, C., \& Huy, Q. N. (2007). How Entrepreneurs Use Symbolic Management to Acquire Resources. Administrative Science Quarterly, 52(1), 70-105. https://doi.org/10.2189/asqu.52.1.70

\section{Appendix A}

Table A1

Measurement scale.

Variable (Code)

\begin{tabular}{|c|c|c|}
\hline & & $\begin{array}{l}\text { from previous studies or } \\
\text { self-developed }\end{array}$ \\
\hline \multirow{3}{*}{$\begin{array}{l}\text { Managerial political } \\
\text { ties (MPT) }\end{array}$} & Political leaders at various levels of the government. (MTP1) & \multirow[t]{3}{*}{ (Li \& Zhou, 2010) } \\
\hline & Officials in industrial bureaus. (MTP2) & \\
\hline & $\begin{array}{l}\text { Officials in regulatory and supporting organizations such as tax } \\
\text { bureaus, state banks, commercial administration bureaus, and the } \\
\text { like (MTP3) }\end{array}$ & \\
\hline \multirow[t]{4}{*}{$\begin{array}{l}\text { Institutional support } \\
\text { (IS) }\end{array}$} & $\begin{array}{l}\text { The government often implements policies and programs beneficial } \\
\text { to our operations (IS1) }\end{array}$ & \multirow[t]{4}{*}{$\begin{array}{l}\text { (Guo et al., 2014; Li \& } \\
\text { Zhou, 2010) }\end{array}$} \\
\hline & The government provides us with much useful information. (IS2). & \\
\hline & $\begin{array}{l}\text { The government often helps us obtain licenses such like an import } \\
\text { license or a technical license (IS3) }\end{array}$ & \\
\hline & $\begin{array}{l}\text { The government provides us with securing local resources such as } \\
\text { land, electricity, and human resources (IS4). }\end{array}$ & \\
\hline \multirow[t]{4}{*}{$\begin{array}{l}\text { Opportunity } \\
\text { Recognition (OR) }\end{array}$} & $\begin{array}{l}\text { Recognizing opportunities from the new establishment or the } \\
\text { adjustment of industrial policies and planning (OR1) }\end{array}$ & \multirow[t]{2}{*}{ (Guo et al., 2014) } \\
\hline & $\begin{array}{l}\text { Recognizing opportunities by communicating with government } \\
\text { officials (OR2) }\end{array}$ & \\
\hline & $\begin{array}{l}\text { Recognizing opportunities from new free trade agreements in } \\
\text { Vietnam (OR3) }\end{array}$ & \multirow[t]{2}{*}{$\begin{array}{l}\text { Developed from the in- } \\
\text { depth interviews }\end{array}$} \\
\hline & $\begin{array}{l}\text { We have well prepared to predict the outcome of the upcoming } \\
\text { trade agreements (OR4) }\end{array}$ & \\
\hline \multirow{4}{*}{$\begin{array}{l}\text { Regulatory Legitimacy } \\
\text { (RL) }\end{array}$} & What we do are authorized by the government (RL1) & \multirow[t]{4}{*}{ (Guo et al., 2014) } \\
\hline & What we do confirm with the policies, rules and regulations (RL2) & \\
\hline & $\begin{array}{l}\text { What we do correspond to the government's thinking of possible } \\
\text { policy adjustments (RL3) }\end{array}$ & \\
\hline & $\begin{array}{l}\text { What we do often become industrial templates as recommended by } \\
\text { the government (RL4). }\end{array}$ & \\
\hline \multirow{6}{*}{$\begin{array}{l}\text { Training activities } \\
\text { (TA) }\end{array}$} & Training for fire protection (TA1) & \multirow{6}{*}{$\begin{array}{l}\text { Developed from the in- } \\
\text { depth interviews }\end{array}$} \\
\hline & Training on labor safety (TA2) & \\
\hline & Informing new policies for FDI firms (ex post facto) (TA3) & \\
\hline & $\begin{array}{l}\text { Providing information about the commitment of trade and market } \\
\text { information (TA4) }\end{array}$ & \\
\hline & $\begin{array}{l}\text { Informing the transparency of information and policies related to } \\
\text { business (TA5) }\end{array}$ & \\
\hline & Organizing business seminars and business meetings (TA6) & \\
\hline \multirow{6}{*}{$\begin{array}{l}\text { Firm performance } \\
\text { (FP) }\end{array}$} & Market share growth (FP1) & \multirow{6}{*}{$\begin{array}{l}\text { (Guo et al., 2014; Jayaram } \\
\text { \& Tan, 2010) }\end{array}$} \\
\hline & Sales growth (FP2) & \\
\hline & Profit growth (FP3) & \\
\hline & Return on assets (FP4) & \\
\hline & Product quality (FP5) & \\
\hline & Customer service level (FP6) & \\
\hline
\end{tabular}

(IS)

Adapted and modified from previous studies or self-developed

Officials in industrial bureaus. (MTP2) like (MTP3)

to our operations (IS1)

Item

(Guo et al., 2014; Li \&

Zhou, 2010)

Developed from the indepth interviews

Developed from the in-

(Guo et al., 2014; Jayaram

\& Tan, 2010) 
(C) 2020 by the authors; licensee Growing Science, Canada. This is an open access article distributed under the terms and conditions of the Creative Commons Attribution (CC-BY) license (http://creativecommons.org/licenses/by/4.0/). 